\title{
Relationship between Job Satisfaction, Working Conditions, Motivation of Teachers to Teach and Job Performance of Teachers in MTs, Serang, Banten
}

\author{
Mohammad Amin ${ }^{1}$ \\ ${ }^{1}$ Lecturer of IAIN Sultan Maulana Hasanudin, Banten, Indonesia \\ Correspondence: Mohammad Amin, Lecturer of IAIN Sultan Maulana Hasanudin, Banten, Indonesia. E-mail: \\ mohamin070@gmail.com
}

Received: April 17, 2015 Accepted: May 25, 2015 Online Published: August 28, 2015

doi:10.5539/jms.v5n3p141ＵRL: http://dx.doi.org/10.5539/jms.v5n3p141

\begin{abstract}
The purpose of this study is to investigate and analyze the relationship between job satisfaction, working conditions, motivation of teachers to teach and job performance of teachers in madrasah. The sample was 100 teachers using random sampling technique to the entire population. Research data collection was done by using the research instrument in the form of a questionnaire with Likert scale. The research method was a quantitative method with a descriptive approach, analysis of research data using descriptive statistics and inferential statistics. Research results showed that the level of job performance of teachers, motivation of teachers to teach and job satisfaction and working conditions at school area in the good category. There is a positive relationship between job satisfaction and job performance of teachers. There is a positive relationship between teachers' working conditions with job performance of teachers. There is a relationship between of motivation of teachers to teach with job performance of teachers. There is a relationship between job satisfaction with motivation of teachers to teach. There is an association between working conditions with motivation teach teachers. Based on these results, it can be concluded that the positive improvement in the performance of teachers at school are influenced by job satisfaction, working conditions and motivation of teachers to teach.
\end{abstract}

Keywords: job satisfaction, working condition, motivation of teachers, job performance of teachers

\section{Introduction}

The problem at school is not only limited to the problem of management and teachers, but more broadly, today the quality of education in madrasah very varied and mostly very poor. It can be observed from various aspects, related to the instrumental inputs such as curriculum, teachers, teaching materials; related to environmental inputs such as physical and environmental conditions of the school administration; and related to the process, such as the process of learning, and means necessary infrastructures, as well as related with outputs and outcomes, such as graduates and absorption by the labor market. Therefore, efforts to improve the quality of education in madrasah, include development of curriculum, increasing the professionalism of teachers, fulfillment and other necessary infrastructure being undertaken (Azizy, 2004).

The conditions of madrasah development are: (a) the ability of the management has not been as expected; (b) The level of teacher education most has not been commensurate with the requirements and the ability of the methodology is still low; (c) the ability of teachers to teach madrasah mostly still insists on the introduction of the concept of cognitive and yet insists on religious behavior, social ethics and noble character (Azizy, 2004).

Deterioration due to lack of education in madrasah in the management of school organization, it is as expressed by Uwes (2004) "weakness of Islamic educational institutions that are less capable and can not compete with other educational institutions are lack of institutional organizing skills".

Quality education in madrasah is strongly influenced by elements including qualified teachers and school management It is confirmed by the results of research conducted in China by Cheng and Wong (2005), finding four characteristics of elementary schools that excel, namely: (1) the existence of a consistent support of public education, (2) the high degree of professionalism among teachers, (3) the existence of a tradition of quality assurance of the school, and (4) the presence of high expectations of students to excel. 
Supriadi (1998) through his research stated "that assessed the quality of education of learners' learning achievement is determined by the teacher, which is $34 \%$ in developing countries and $36 \%$ in industrialized countries". According Mulyasa (2007) there should be at least seven indicators of poor performance in carrying out its main task teacher teaching, namely: (a) the low understanding about learning strategies, (b) lack of proficiency in classroom management, (c) lack of ability to perform and utilize class action research, (d) low achievement motivation, (d) lack of commitment to the profession, (e) to the low capacity of the maintenance period.

Teacher performance is decreasing in the works, due to the lack of job satisfaction of a teacher. Bishay said that true job satisfaction is derived from the gratification of higher order needs, social relations, esteem, and actualization, rather than the lower order needs (Bishay, 1996).

Based on the results of studies in developing countries, teachers contribute to student achievement (36\%), furthermore, management $(23 \%)$, time to learn $(22 \%)$, and physical facilities $(19 \%)$. Aspects relating to the teacher are the image / quality of teachers and welfare (Sidi, 2000).

In addition, factors that influence the achievement of teachers according to Davis (2004) are also decisive in the achievement of the work situation, work environment or atmosphere of the organization, namely the extent to which someone likes responsibility based on his work. How good relationship with the association is based on and how much the incentives provided by the efforts made in his work.

Teaching motivation encourages the teachers to produce quality learning process. Teachers also want to get a strong urge to do their job at school. Teachers who have high motivation in teaching have high achievement. To move forward and have a high achievement in the implementation of the learning process in madrasah, teachers need encouragement and efforts to develop, improve loyalty and commitment to the profession and receive the award.

This research was conducted on the madrasah teachers. To improve the performance of teachers needs optimally a variety of resources including teachers' motivation, job satisfaction as well as a good working atmosphere. These factors are key factors for improving the achievement of teachers and that research has a clear focus on the aspects of the job performance of teachers in MTs State in Serang, Banten. This study is limited to issues specific to: 1) The relationship between job satisfaction and job performance of teachers; 2) The relationship between working conditions and job performance of teachers; 3) The relationship between motivation of teachers and job performance of teachers; 4) The relationship between job satisfaction and motivation of teachers; 5) The relationship between working conditions and motivation of teachers.

The hypothesis of this study is that there is a positive relationship between job satisfaction and job performance of teachers. There is a positive relationship between working conditions and job performance of teachers. There is a positive relationship between motivation of teachers and teacher job performance. There is a positive relationship between job satisfaction and motivation of teachers to teach. There is a positive relationship between working condition with motivation of teachers.

\section{Literature Review}

\subsection{Job satisfaction}

Luthans (2006) found that job satisfaction is a happy or positive emotion derived from the assessment of a person's job or work experience.

Satisfaction comes from within a person, in this case is derived from the inner of teacher. A teacher who has a good job satisfaction, has a positive emotion towards his job and who have low job satisfaction has a negative emotion towards work. High or low achievement can be determined by the teacher's satisfaction in work.

Sutrisno (2009) stated that job satisfaction is an attitude of employees towards work related to the work situation, cooperation among employees, remuneration in employment, and matters relating to the physical and psychological factors.

Robbins (2003) also stated that job satisfaction refers to an individual's general attitude towards work. A high level of job satisfaction will show a positive attitude toward the job, and it also works in reverse. Job satisfaction came from various aspects of work, such as wages, promotion, supervision, co-workers, and also the work environment factors, policies and procedures, membership of the working group, working conditions and benefits (Gibson et al., 1997). 
Gibson et al. (1997) stated that job satisfaction is a person's attitude toward his work; the brush is derived from his perception of the job. Also Siagian (2006) said job satisfaction is a person's perspective, positive or negative attitude towards work.

Teacher's job satisfaction is a pleasant feeling about the job based on the expectations of teachers with consideration given by the school (Suwar, 2008). Teacher's job satisfaction is indicated by its position in the work or teaching. If the teacher is satisfied with circumstances affecting him, he will work or teach well.

Sopiah (2008) described that job satisfaction is a person's emotional responses to the situation and working conditions. Emotional responses can be a feeling of satisfaction (positive) or not satisfied (negative). When emotionally satisfied means of job satisfaction is achieved and vice versa if not then it means the employee is not satisfied. Anoraga (2006) revealed that job satisfaction is a positive attitude regarding a healthy adjustment of the employees of the conditions and the employment situation, including the issue of wages, social conditions, physical and psychological condition.

The statement above is reinforced by statements by Kreitner and Kinicki (2003) which define job satisfaction as an effective or emotional response to various aspects of the work. Satisfaction is the individual's general attitude towards work.

Azeem (2010) stated there are five aspects that affect job satisfaction, namely: the work itself; salary; supervision; promotional opportunities; relationships with fellow workers.

Research conducted by Lo and Ramayah (2011) found that the good done on the job mentoring itself, promotion, supervision, leadership, and the working group will lead to job satisfaction. Similarly, Boles et al. (2007) described that aspects of job satisfaction are related to affective commitment of employees.

Job satisfaction of an individual depends on the individual characteristics and job situation. Understanding also implies, job satisfaction is an individual thing. Each individual will have the satisfaction of differing stages in accordance with the prevailing value system.

\subsection{Working Environment}

Working environment or the working condition is a condition that is located around the employees and can affect the employee in carrying out any daily work activities (Siagian, 2002).

Stimulating working atmosphere boosts morale of organizations to do more to achieve the goals (Siagian, 1986). Headmaster and teachers communicate openly to build a conducive atmosphere so that the whole school power can be focused on achieving the goals of education in madrasah. The existence of a conducive working atmosphere in the madrasah will have a considerable influence on the learning process at the school; the teacher can concentrate on the acquisition and delivery of materials to achieve better academic achievement and students will feel comfortable in learning, which becomes essential in the learning activities at school.

There are some common problems that can lead to unpleasant atmosphere: attitude or emotional leadership behaviors, negative thinking, always looking at the negative side of men, angry in public; the friction or discord among men; tackling each other among employees; mutual envy of the position and other employees of the facility; provoking one another, among the employees provocateur especially if supported by superiors; attitudes that exaggerate the problem; the less harmonious relationship between employees and management; companies that are in financial difficulties; cliquish, exclusive group; looking for a scapegoat (Poerwopoespito \& Utomo, 2000).

Encouraging conducive working atmosphere in madrasah can be initiated with the cooperation between the components of the madrasah. Adams (2006) stated school leaders can foster teamwork in solving the problem, involving the school community in decision-making and the entire staff are encouraged to reach their potential. Thus, good interpersonal relationship among the members manifested a conducive working atmosphere (Fink \& Brayman, 2006).

Conducive atmosphere at school is very necessary. In order to create a conducive atmosphere, the teacher has an important position because the activities in the madrasah education are dominated by the teacher. Therefore the teacher becomes an indicator in the changes of working atmosphere in madrasah.

\subsection{Motivation of Teachers to Teach}

Motivation is defined as the complex of forces, drive, need, tension states, or other internal mechanisms that short psycological and maintain activity toward the achievement of personal goals (Hoy \& Miskel, 1978). 
Davis (2004) mentioned the motivation has four patterns, namely: (1) achievement motivation, the urge to master the challenges, for developed and developing; (2) motivation affiliate, the urge to connect with people effectively; (3) motivation competence, an encouragement to achieve work with high quality, improve problem-solving skills, and strive to innovate; (4) motivation power, an encouragement to influence people and change the status.

Abraham Maslow's opinion can be concluded that the motivation to teach: (1) motif physiology: encouragement and teachers for outstanding efforts in implementing innovative learning is always there, a drive to master the challenges, to grow and progress in the implementation of learning; (2) security motives: encouragement and affiliated effort, an urge to connect with people effectively, competent, an encouragement to achieve work with high quality, improve problem-solving skills, and strive to innovate, the need for an award; (3) the motive of brotherhood: encouragement and efforts of teachers to receive the award, which includes the need rewarded for achievement, ability, position, or status, and rank; (4) self-esteem motive: that is gaining recognition, appreciation and respect of others, 5) the motive of self-actualization: the need for self-actualization aitu encouragement and efforts to enhance the competence of teachers, development potential, creativity, and expression of optimal (Robbins, 2001).

A teacher has a responsibility as an educator. The responsibility of the teacher covers all the activities that must be carried out before giving or delivering instructional materials; review the teaching materials, develop the boundaries of the planning exercise, prepare a list of values to define the level and knowledge of trainees etc. (Sartika, 1999).

The teacher as an educator needs a good productivity. Sanusi disclosed productive individuals, namely (a) actions constructive, (b) believe in yourself, (c) charge, (d) have a love of work, (e) have the foresight, (f) be able to overcome and can adapt to a changing environment, (g) have innovative contribution, (h) have the power to realize its potential, and (i) have the ability to: such as skills, knowledge, qualification, experience and characteristics (Sanusi, 1992).

\subsection{Job Performance of Teachers}

Manullang (2008) found that people who have a great need for achievement have characteristics which are: 1) the responsibility to suss out the problem; 2) determine the difficult goals for themselves and to quantify the risk; 3 ) priority importance of feedback. While the specific characteristics of people who have the achievement motive are: 1) excited if superior; 2) willing to take calculated risks; 3) would be responsible; 4) selecting a challenging task; 5) requires feedback; 6) work not for money or reward.

Activities undertaken by a person can not be separated from the behavior of the display so as to provide results on goal. As stated by Gagne and Briggs (1979), job performance is also related to all activities or behaviors that we experience and can be displayed through the answers that we created to give results or objectives. Job performance is a result of work achieved in executing the tasks assigned to them based on the skills, experience, and the seriousness and time (Hasibuan, 1996).

But the simple performance or work performance by As'ad (1995) is the role of success or achievement obtained by a person of his job. Achievement is an assessment of a person by conduct in performing work tasks either individually or in groups within an organization. The assessment of the employee's performance is not only assess the results of the physical, but also the overall execution of the work related to various fields such as, the ability to work, craft discipline, employment or particulars in accordance with the field and the level of employment (Soeprihatno, 1996).

Performance to meet the standards is considered as satisfactory if the statement indicates some key areas of responsibilities of employees, makes how a work activity will be carried out and draws attention to the quantitative mechanism of how the results of the performance will be measured (Tempe, 1992).

Good performance is characterized by the passion of employees who carry out the work in accordance with the regulations, as well as a willingness to cooperate with other employees in achieving the company's goals. There are several factors that affect job performance: personality, abilities and skills (Flippo, 1995). Where the personality, abilities and skills possessed employees will have an impact on work performance, work activities, behavior, and performance are set to carry on certain results (outcomes). It is presented by Donnelly, Gibson and Ivancevich (1984) in the form of Figure 1. 


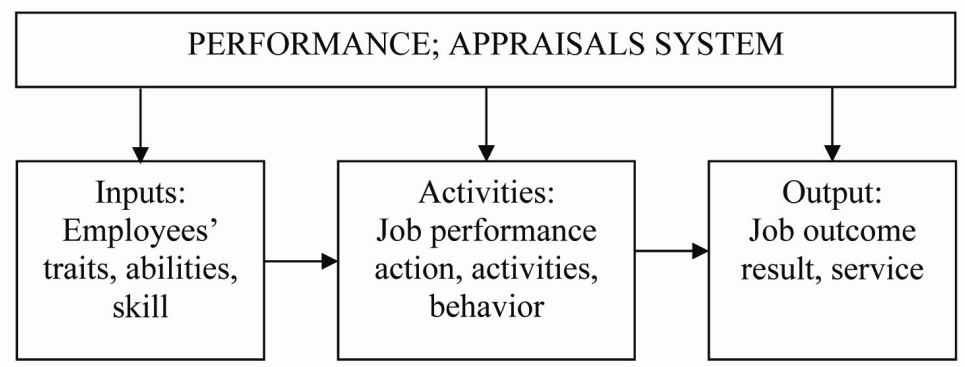

Figure 1. Factors affect job performance

Source: Donnelly, Gibson, \& Ivancevich (1984).

To assess the performance of employees require certain methods for the appraisal to bring benefits to the organization. It is as expressed by Heidjrachman and Husnan (1997) system or method that can be used to assess job performance are: rank; comparison of employees with employees (person to person comparison); graphic scale; checlists.

With so many choices, the performance appraisal methods and techniques that will be selected for a program can be tailored to the circumstances of the organization. Based on theories, it can be concluded that the performance is a variety of activities or behavior of employees in carrying out the duties, roles and responsibilities in order to obtain the work in accordance with its intended purpose in an organization.

\section{Research Methods}

The method used is quantitative research method. The most appropriate method of quantitative review used to see the relationship between the variables (Kerlinger, 1993). Based on the properties of the problem, this research is correlational research. Correlation study aims to detect the extent of variations on a factor related to variations in one or more other factors based on the correlation coefficient (Suryabrata, 1992).

This research essentially intended to get an idea of how much the relationship of independent variables with the dependent variable. There are four variables in this study: teacher's job satisfaction, working conditions, motivation of teachers, and job performance of teachers.

Quantitative research in this study uses descriptive method, which is to find out the facts with proper interpretation, including studies to accurately describe the nature of some phenomenon, groups or individuals (Nazir, 1988). Descriptive research is a research method that is trying to describe the object or subject under study in accordance with what is (Best, 1982).

Data collection is conducted by questionnaire instrument. The instrument used in this study is a questionnaire compiled by Likert scale models.

These instruments include measuring teacher's performance and motivation of teachers as the dependent variable, while the independent variables are job satisfaction and working conditions. Also the analysis uses statistical techniques, both descriptive statistics and inferential statistics; descriptive statistics presents the average values and standard deviations, while inferential statistics are used to test the research hypothesis.

The hypothesis is: 1) there is a positive and significant relationship between job satisfaction and job performance of teachers; 2) there is a positive and significant relationship between working conditions and job performance of teachers; 3 ) there is a positive and significant relationship between motivation of teachers and job performance of teachers; 4) there is a positive and significant relationship between job satisfaction and motivation of teachers; 5) there is a positive and significant relationship between working conditions and motivation of teachers.

\section{Research}

\subsection{Descriptive Study}

More descriptive statistical methods are associated with collecting and summarizing the data, and presenting the results of these cuts. Description calculation results are explained as follows:

Teachers' performance scores are obtained from measurements by using questionnaires. The calculation of descriptive statistics obtains an average score for the dimension employees traits abilities at 22.73, the dimension skill at 26.01, the dimension job performance action at 22.39 and the dimension activities behavior at 27.61, standard deviation values for employees traits abilities at 4.694, dimension skill at 51.34, dimension job 
performance action at 4.355 , and the dimension activities behavioral at 4.251 . The overall performance of the teachers has an average value of 98.74, standard deviation value 11.825 . Thus it can be seen that the performance of the overall madrasah teachers is in good condition.

From the calculation of descriptive statistics, it obtains an average score for the variable of teacher motivation on the dimension of motive physiology at 19.48 , motive security at 22.85 , brotherhood motifs at 20.64 , motifs esteem at 15.73, and self-actualization motive at 17.63. Standard deviation score on the dimension motif physiology is 3.727 , security motive 4.064 , motive fraternity 4.811 , self-esteem motive 4.178 , and the motive of self-actualization 3.246. Overall for motivation of teachers to teach, the average value is 96.33 and standard deviation value is 11.784 . Thus it can be said that teachers in madrasah have good motivation.

From the calculation of descriptive statistics teacher job satisfaction variables it obtains an average score of the dimension work itself at 20.04, dimension salary 22.96, dimension control 21.67, promotion opportunities 16.02 , relationships with fellow workers at 17.02. Standard deviation value of the dimension work itself is 5.375 , dimension salary 4.761, supervision 5.453, amounting promotional opportunities 3.952, relationships with fellow workers 3.449. The average value of overall job satisfaction is 97.71, and standard deviation value is 15.727 . It can be concluded that overall job satisfaction held by teachers at school is in good condition.

From the calculation of descriptive statistics working conditions variables it obtains an average score of a pleasant working environment at 15.98 , labor availability at 18.76 , clarity of tasks for each member at 22.06 , and work programs organized neatly at 21.57 . The standard deviation value for the dimension a pleasant working environment is 3.266 , the dimension availability of work 4.367 , the dimension clarity duties of each member 4.415 , the dimension the work program is neatly organized 5.159 . Overall working conditions variable has an average value of 77.37 and a standard deviation value of 10.311. From the descriptive results can be seen that the working conditions at school are good.

Thus it can be said that the working conditions are very well established in madrasah. The existence of good working conditions gives a sense of comfort and tranquility. Overall value of the research variables, teachers job performance, motivation of teachers, job satisfaction and working environment can be summarized in Table 1 below:

Table 1. Summary of descriptive variables

\begin{tabular}{|c|c|c|c|}
\hline Variables & Dimention & Mean & $\begin{array}{l}\text { Standard } \\
\text { Deviation }\end{array}$ \\
\hline \multirow[t]{5}{*}{ Teacher's job performance } & & 98.74 & 11,825 \\
\hline & Employees traits abilities & 22.73 & 4.694 \\
\hline & Skill & 26.01 & 5.134 \\
\hline & Job performance action & 22.39 & 4.355 \\
\hline & Activities behavior & 27.61 & 4.251 \\
\hline \multirow[t]{6}{*}{ Motivation of teachers } & & 96.33 & 11.784 \\
\hline & Motif physiology & 19.48 & 3.727 \\
\hline & Motif security & 22.85 & 4.064 \\
\hline & Motif fraternity & 20.64 & 4.811 \\
\hline & Motif-esteem & 15.73 & 4.178 \\
\hline & Motive of self actualization & 17.63 & 3.246 \\
\hline \multirow[t]{6}{*}{ Job satisfaction of teachers } & & 97.71 & 15.727 \\
\hline & The work itself & 20.04 & 5.375 \\
\hline & salary & 22.96 & 4.761 \\
\hline & supervision & 21.67 & 5.453 \\
\hline & promotion opportunities & 16.02 & 3.952 \\
\hline & Relationships with co-workers & 17.02 & 3.449 \\
\hline \multirow[t]{5}{*}{ Working conditions } & & 77.37 & 10.311 \\
\hline & Pleasant working environment & 15.98 & 3.266 \\
\hline & The availability of work & 18.76 & 4.367 \\
\hline & clarity of tasks of each member & 22.06 & 4.415 \\
\hline & The work program is organized & 21.57 & 5.159 \\
\hline
\end{tabular}




\subsection{Correlation Study}

\subsubsection{Relationship between Job Satisfaction and Job Performance}

Test the hypothesis: There is a positive relationship between job satisfaction and job performance of teachers.

Relationship of job satisfaction and teacher performance can be seen in Table 2. The variable job satisfaction with the performance of the teachers have the value of the relationship $(\mathrm{r}=0621)$ showing the overall relationship of job satisfaction with teacher performance significantly. Table 2 shows that the dimension the work itself does not have a relationship with behavioral activities.

Dimension the work itself has a relationship with the dimension abilities of employees traits $(r=0.657)$, skill ( $r$ $=0.404)$, the dimension action with job performance $(\mathrm{r}=0.215)$, as well as the performance $(\mathrm{r}=0.519)$. Salary dimension has relationships with employees traits abilities $(r=0.321)$, the skill $(r=0.444)$, with a performance equal to $(\mathrm{r}=0.368)$. Dimension supervision with skill dimension $(\mathrm{r}=0.241)$, the action of job performance $(\mathrm{r}=$ $0.418)$, the behavior of activities $(0.282)$, as well as the performance $(\mathrm{r}=0.402)$. Dimension promotional opportunities with abilities of employees traits $(r=0.383)$, the action of job performance $(r=0.333)$, antivities behavior $(r=0.437)$, as well as the performance $(r=0.514)$. Dimension relationship with fellow workers with dimension behavior activities $(r=0.301)$ and with the work performance of $(r=0.291)$ and job satisfaction with dimension abilities of employees traits $(r=0.480)$, the skill $(r=0.444)$, with dimension job performance action $(\mathrm{r}=0.353)$, with dimension behavior for activities $(\mathrm{r}=0.294)$, as well as the achievement work for $(\mathrm{r}=0.621)$. Adaptive research the relationship between job satisfaction and job performance of teachers can be seen in table 2 below:

Table 2. Relationship between job satisfaction and job performance

\begin{tabular}{llllll}
\hline & $\begin{array}{l}\text { Employees } \\
\text { traits abilities }\end{array}$ & Skill & $\begin{array}{l}\text { Job } \\
\text { performance } \\
\text { action }\end{array}$ & $\begin{array}{l}\text { Activities } \\
\text { behavior }\end{array}$ & $\begin{array}{l}\text { Job } \\
\text { performance }\end{array}$ \\
\hline The work itself & $.657^{* *}$ & $.404^{* *}$ & $.215^{*}$ & .011 & $.519^{* *}$ \\
salary & .000 & .000 & .032 & .910 & .000 \\
& $.321^{* *}$ & $.444^{* *}$ & .073 & .055 & $.368^{* *}$ \\
supervision & .001 & .000 & .468 & .585 & .000 \\
promotion opportunities & .100 & $.241^{*}$ & $.418^{* *}$ & $.282^{* *}$ & $.402^{* *}$ \\
& .323 & .016 & .000 & .004 & .000 \\
Relationships with co-workers & $.383^{* *}$ & .180 & $.333^{* *}$ & $.437^{* *}$ & $.514^{* *}$ \\
Job satisfaction & .000 & .073 & .001 & .000 & .000 \\
& .123 & .193 & .130 & $.301^{* *}$ & $.291^{* *}$ \\
& .222 & .055 & .198 & .002 & .003 \\
\hline
\end{tabular}

$* *$ Significant at $\mathrm{p}<0.05$

\subsubsection{Relationship between Workinging Conditions and Job Performance}

Test the hypothesis: There is a positive relationship between working conditions and job performance of teachers.

Relationship between the working conditions and work performance can be seen in Table 3, which shows that the overall working conditions have a strong relationship with the teacher job performance $(r=0.688)$. The dimension the working conditions do not have a relationship with work performance, i.e., the dimension pleasant working conditions with job performance action $(r=0.162)$, with activities behaviors $(r=-0.003)$, the dimension the availability of work with the dimension job performance action $(\mathrm{r}=0.122)$, the dimension behavior activities $(r=0.058)$, the dimensions the clarity of each member's duties with dimension abilities traits $(r=0.114)$, the dimension behavior activities $(r=0.066)$, dimension work program organized by skill $(r=0.054)$.

Dimension pleasant working environment has a relationship with dimension employess abilities traits $(r=0.558)$, with dimension skill $(\mathrm{r}=0.317)$ and with work performance $(\mathrm{r}=0.417)$. The dimension the availability of work with employees abilities traits $(r=0.448)$, with dimension skill $(r=0.378)$, as well as with work performance variable $(r=0.408)$. Dimension clarity duties of each member of the skill dimension $(r=0.514)$, with dimension job performance action $(r=0.385)$, as well as with job performance $(r=0.435)$, the dimension organized labor 
profeam employess dimensional abilities traits $(r=0.222)$, with dimension job performance action $(r=0.336)$, with dimension behavioral activities $(r=0.430)$ and with work performance variable $(r=0.394)$. Variable working conditions has a relationship with all dimensions of job performance by employees abilities traits $(\mathrm{r}=$ $0.527)$, skill $(\mathrm{r}=0.508)$, job action performance $(\mathrm{r}=0.436)$, activities behavior $(\mathrm{r}=0.267)$.

Table 3. Relationship between working conditions and teacher job performance

\begin{tabular}{|c|c|c|c|c|c|}
\hline Wob Performance & $\begin{array}{l}\text { Employees } \\
\text { traits abilities }\end{array}$ & Skill & $\begin{array}{l}\text { Job } \\
\text { performance } \\
\text { action }\end{array}$ & $\begin{array}{l}\text { Activities } \\
\text { behavior }\end{array}$ & $\begin{array}{l}\text { Job } \\
\text { Performance }\end{array}$ \\
\hline \multirow[t]{2}{*}{ Pleasant working environment } & $.558 * *$ & $.317 * *$ & .162 & -.003 & $.417 * *$ \\
\hline & .000 & .001 & .108 & .973 & .000 \\
\hline \multirow[t]{2}{*}{ The availability of work } & $.448 * *$ & $.378 * *$ & .122 & .058 & $.408 * *$ \\
\hline & .000 & .000 & .227 & .565 & .000 \\
\hline \multirow[t]{2}{*}{ Clarity task of each member } & .114 & $.514 * *$ & $.385 * *$ & .066 & $.435 * *$ \\
\hline & .257 & .000 & .000 & .515 & .000 \\
\hline \multirow[t]{2}{*}{ The work program is organized } & $.222 *$ & .054 & $.336^{* *}$ & $.430 * *$ & $.394 * *$ \\
\hline & .026 & .597 & .001 & .000 & .000 \\
\hline \multirow[t]{2}{*}{ Working conditions } & $.527 * *$ & $.508 * *$ & $.436 * *$ & $.267 * *$ & $.688 * *$ \\
\hline & .000 & .000 & .000 & .007 & .000 \\
\hline
\end{tabular}

** Significant at $\mathrm{p}<0.05$

\subsubsection{Relationship between Motivation of Teachers and Teachers' Job Performance}

Test the hypothesis: There is a positive relationship between motivation of teachers and teachers' job performance.

The relationship of teacher's motivation with job performance can be seen in Table 4, which shows that overall motivation variables of teacher has a relationship with job performance of teachers at $(\mathrm{r}=0.775)$, and there are several dimensions of teachers' motivation that does not have a relationship with dimension teacher performance, namely motif action physiology with job performance $(r=0.115)$, the dimension behavior activities $(r=-0.070)$, the dimension security patterns with dimension job performance action $(r=0.172)$, the dimension of behavior activities $(\mathrm{r}=-0.022)$, the dimension brotherhood with employees motive abilities traits $(\mathrm{r}=0.121)$, the dimension self-esteem motive with dimension skill $(\mathrm{r}=0.131)$, and dimension self-actualization motive to dimension abilities employees traits $(r=0.118)$.

There is a relationship between the dimension o the motif physiological and dimension employees traits abilities $(\mathrm{r}=0.596)$, with dimension skill $(\mathrm{r}=0.301)$, as well as with work performance variables $(\mathrm{r}=0.384)$, the dimension security patterns has a relationship with dimension traits employees abilities $(r=0.374)$, with dimension skill $(\mathrm{r}=0.671)$, as well as with work performance $(\mathrm{r}=0.495)$, dimension motif has fraternal relations with the dimension skill $(\mathrm{r}=0.335)$, action job performance $(\mathrm{r}=0.573)$, behavioral activities $(\mathrm{r}=0.287)$, as well as the performance of $(\mathrm{r}=0.510)$, the dimension of self-esteem motive has relationship with employees traits abilities $(r=0.201)$, with dimension of job performance action $(r=0.280)$, with activities behaviors $(r=0.485)$ along with teacher job performance $(\mathrm{r}=0.419)$, the dimension self-actualization motive has a relationship with the skill $(\mathrm{r}=0.228)$, with an action job performance $(\mathrm{r}=0.291)$, with dimension behavioral activities $(\mathrm{r}=0.560)$, and the job performance of teachers $(\mathrm{r}=0.459)$, as well as teaching and teacher motivation variables have a relationship to all dimension of job performance that the dimension traits employees abilities $(\mathrm{r}=0.471)$, with dimension skill $(\mathrm{r}=0.572)$, with dimension job performance action $(\mathrm{r}=0.509)$, with activities behaviors $(\mathrm{r}=$ 0.414). 
Table 4. Relationship between motivation of teachers and job performance

\begin{tabular}{|c|c|c|c|c|c|}
\hline Motivation & $\begin{array}{l}\text { Employees } \\
\text { traits abilities }\end{array}$ & Skill & $\begin{array}{l}\text { Job } \\
\text { performance } \\
\text { action }\end{array}$ & $\begin{array}{l}\text { Activities } \\
\text { behavior }\end{array}$ & $\begin{array}{l}\text { Work } \\
\text { Performance }\end{array}$ \\
\hline \multirow[t]{2}{*}{ Motif physiology } & $.596 * *$ & $.301 * *$ & .115 & -.070 & $.384 * *$ \\
\hline & .000 & .002 & .253 & .489 & .000 \\
\hline \multirow[t]{2}{*}{ Motif security } & $.374 * *$ & $.671 * *$ & .172 & -.022 & $.495 * *$ \\
\hline & .000 & .000 & .087 & .826 & .000 \\
\hline \multirow[t]{2}{*}{ Motif fraternity } & .121 & $.335 * *$ & $.573 * *$ & $.287 * *$ & $.510 * *$ \\
\hline & .231 & .001 & .000 & .004 & .000 \\
\hline \multirow[t]{2}{*}{ Motif-esteem } & $.201 *$ & .131 & $.280 * *$ & $.485 * *$ & $.419 * *$ \\
\hline & .045 & .194 & .005 & .000 & .000 \\
\hline \multirow[t]{2}{*}{ Motive of self actualization } & .118 & $.228 *$ & $.291 * *$ & $.560 * *$ & $.459 * *$ \\
\hline & .242 & .022 & .003 & .000 & .000 \\
\hline \multirow[t]{2}{*}{ Motivation of teachers } & $.471 * *$ & $.572 * *$ & $.509 * *$ & $.414 * *$ & $.775 * *$ \\
\hline & .000 & .000 & .000 & .000 & .000 \\
\hline
\end{tabular}

** Significant at $\mathrm{p}<0.05$.

\subsubsection{Relationship between Job Satisfaction and Motivation of Teachers}

Test the hypothesis: There is a positive relationship between job satisfaction and motivation of teachers to teach.

The relationship between job satisfaction and motivation of teachers teaching can be seen in Table 4, overall job satisfaction has a relationship with the teacher teaching motivation $(\mathrm{r}=0.723)$, there are several dimensions that do not have the dimension employment relationship itself with self-actualization motive dimension $(r=0.150)$, the dimension salary do not have a relationship with the self-esteem motive dimension $(r=0.158)$, dimensional control, with dimension physiology motif $(r=0.115)$, with dimensions motives of self-esteem $(r=0.183)$, the dimension promotional opportunities with dimensions physiology motif $(r=0.186)$, the dimension the relationship with fellow workers with physiology motive dimension $(r=0.068)$, with dimension security motif $(r$ $=0.153)$, and with dimension brotherhood motifs $(\mathrm{r}=0.196)$.

On the contrary, the dimension the work itself has a relationship with physiology motive dimension $(r=0.646)$, the dimension security motif $(\mathrm{r}=0428)$, the dimension brotherhood motifs $(\mathrm{r}=0.276)$, as well as the dimension the motive of self-esteem $(r=0.215)$ and with the motivation teaching $(r=0.582)$. Dimensions salary has ties with the physiology motif $(r=0.322)$, with dimension security motif $(r=0.466)$, with dimension brotherhood motifs $(\mathrm{r}=0.279)$, with the motive of self-actualization dimension $(\mathrm{r}=0.204)$, as well as the motivation to teach $(\mathrm{r}=0.489)$. Dimension control has a relationship with security motif $(\mathrm{r}=0.258)$, with dimension brotherhood motifs $(r=0.453)$, with the motive of self-actualization dimension $(r=0.326)$, as well as the motivation to teach $(r=0.465)$. Dimension promotional opportunities linked to the security motive dimension $(r=0.197)$, with the motive of brotherhood $(r=0.285)$, with dimensions motives of self-esteem $(r=0605)$, with the motive of self-actualization $(r=0.331)$, as well as the motivation of teaching $(r=0.549)$. Dimensions relationship with fellow workers with self-esteem motive dimension $(r=0.218)$, with dimension self-actualization motive $(r=$ $0.434)$ and with the motivation of teaching $(\mathrm{r}=0.351)$. Job satisfaction variables have a relationship with all dimensions of motivation to teach with motifs physiology $(r=0.420)$, with dimension security motif $(r=0.460)$, with brotherhood motifs $(r=0.451)$, with dimensions motives of self-esteem $(r=0.384)$, with dimension self-actualization motive $(\mathrm{r}=0.404)$. 
Table 5. Relationship between Job Satisfaction and Motivation of Teachers

\begin{tabular}{|c|c|c|c|c|c|c|}
\hline Motivation & $\begin{array}{l}\text { Motif } \\
\text { physiology }\end{array}$ & Motif security & Motif fraternity & Motif-esteem & $\begin{array}{l}\text { Motive of self } \\
\text { actualization }\end{array}$ & $\begin{array}{l}\text { Motivation } \\
\text { Teaching }\end{array}$ \\
\hline \multicolumn{7}{|l|}{ Job Satisfaction } \\
\hline \multirow[t]{2}{*}{ The work itself } & $.646 * *$ & $.428 * *$ & $.276^{* *}$ & $.215^{*}$ & .150 & $.582 * *$ \\
\hline & .000 & .000 & .005 & .032 & .137 & .000 \\
\hline \multirow[t]{2}{*}{ Salary } & $.322 * *$ & $.466^{* *}$ & $.279 * *$ & .158 & $.204 *$ & $.489 * *$ \\
\hline & .001 & .000 & .005 & .117 & .042 & .000 \\
\hline \multirow[t]{2}{*}{ supervision } & .115 & $.258 * *$ & $.453 * *$ & .183 & $.326 * *$ & $.465 * *$ \\
\hline & .256 & .010 & .000 & .069 & .001 & .000 \\
\hline \multirow[t]{2}{*}{ promotion opportunities } & .186 & $.197^{*}$ & $.285^{* *}$ & $.605 * *$ & $.331 * *$ & $.549 * *$ \\
\hline & .064 & .049 & .004 & .000 & .001 & .000 \\
\hline Relationships with & .068 & .153 & .196 & $.218 *$ & $.434 * *$ & $.351 * *$ \\
\hline co-workers & .499 & .129 & .051 & .030 & .000 & .000 \\
\hline \multirow[t]{2}{*}{ Job satisfaction } & $.420 * *$ & $.460 * *$ & $.451 * *$ & $.384 * *$ & $.404 * *$ & $.723 * *$ \\
\hline & .000 & .000 & .000 & .000 & .000 & .000 \\
\hline
\end{tabular}

** Significant at $\mathrm{p}<0.05$.

\subsubsection{Relationship between Working Conditions and Motivation of Teachers}

Test the hypothesis: There is a positive relationship between working conditions and motivation of teachers.

Relationship to the working conditions of teacher motivation can be seen in Table 6 , the table can be seen that the overall atmosphere of the work has a relationship with the teacher teaching motivation $(r=0.757)$, there are several dimensions that do not have a relationship that is a pleasant working environment dimension by dimension motif brotherhood $(r=0.185)$ with dimension self-actualization motive $(r=0.124)$, the dimension the availability of work with the dimension self-esteem motive $(\mathrm{r}=0.170)$, as well as the dimension self-actualization motive $(r=0.110)$, the dimension each task clarity each member of the physiology motive dimension $(r=0.065)$, with dimension motives of self-esteem $(r=0.048)$, with the motive of self-actualization dimension $(r=0.153)$, the dimension the work program organized physiology motive dimension $(r=-0.033)$, with dimension security motif $(\mathrm{r}=0.072)$.

Relationship dimensions to the working conditions of teacher motivation dimensional look of a pleasant working environment with physiological motive dimension $(r=0.517)$, security motive dimension $(r=0.319)$, the dimension the motive of self-esteem $(r=0.204)$, as well as the motivation of teachers' teaching $(r=0.455)$. The dimension the availability of work has a relationship with the dimension physiology motif $(r=0.474)$, the dimension security motif $(r=0.458)$, with dimension brotherhood motifs $(r=0.225)$, as well as the motivation of teachers' teaching $(r=0.490)$. Dimensions clarity duties of each member has a relationship with the security motive dimension $(r=0.450)$, with dimension brotherhood motifs $(r=0.489)$, with teaching motivational variables $(r=0.435)$. Dimensions program organized labor has a relationship with the dimension brotherhood motifs $(\mathrm{r}=0.336)$, with dimension self-esteem motive $(\mathrm{r}=0.606)$, with dimension actualization motif $(\mathrm{r}=0.260)$, as well as the motivation to teach $(r=0.438)$. As well as working atmosphere has a relationship with the entire dimension is the dimension of teacher motivation motive physiology $(r=0.376)$, the dimension security motif $(r$ $=0.524)$, the dimension brotherhood motifs $(r=0.531)$, self-esteem motive dimension $(r=0.460)$, dimensions motive of self actualization $(\mathrm{r}=0.281)$. 
Table 6. Relationship between working conditions and motivation of teachers

\begin{tabular}{lllllll}
\hline \multicolumn{1}{r}{ Motivation Teaching } & $\begin{array}{l}\text { Motif } \\
\text { physiology }\end{array}$ & Motif security & Motif fraternity & Motif-esteem & $\begin{array}{l}\text { Motive of self } \\
\text { actualization }\end{array}$ & $\begin{array}{l}\text { Motivation } \\
\text { Teaching }\end{array}$ \\
Working Conditions & & & & & & $.455^{* *}$ \\
Pleasant working & $.517^{* *}$ & $.319^{* *}$ & .185 & $.204^{*}$ & .124 & .000 \\
environment & .000 & .001 & .066 & .042 & .219 & $.490^{* *}$ \\
The availability of work & $.474^{* *}$ & $.458^{* *}$ & $.225^{*}$ & .170 & .110 & .000 \\
& .000 & .000 & .025 & .090 & .277 & $.435^{* *}$ \\
Clarity task of each & .065 & $.450^{* *}$ & $.489^{* *}$ & .048 & .153 & .000 \\
member & .520 & .000 & .000 & .635 & .128 & $.438^{* *}$ \\
The work program is & -.033 & .072 & $.336^{* *}$ & $.606^{* *}$ & $.260^{* *}$ & .000 \\
organized & .746 & .479 & .001 & .000 & .009 & $.757^{* *}$ \\
Working conditions & $.376^{* *}$ & $.524^{* *}$ & $.531^{* *}$ & $.460^{* *}$ & $.281^{* *}$ & .000 \\
\hline
\end{tabular}

** Significant at $\mathrm{p}<0.05$.

\section{Discussion}

Stage performance of teachers, teaching motivation, job satisfaction and the working atmosphere at the school is high. It is revealed from the results of research conducted teacher job satisfaction and working conditions linked to motivation and performance of teachers teaching teachers. It could be argued that if the teacher job satisfaction and working atmosphere in madrasah increased good, will positively affect teachers' motivation and job performance of teachers.

Teachers carry out their duties and obligations as a good educator. Teachers need to maintain the creativity, competence and professionalism, in order to improve the quality of the learning process at school. Some principles which are common to all good teachers are (1) understand and respect the students; (2) respect the lesson material; (3) adjust teaching methods to the learning materials; (4) teach materials with the ability to adjust the individual; (5) enable students in learning; (6) give sense and not just mere words; (7) connect lessons to the needs of students; (8) have a certain set goals with each lesson provides; (9) should not be bound by the textbook. (10) not only taught in the sense of conveying knowledge to students but always only personal development of children (Nasution, 2000).

Gibson (1997) stated that the motivation will make the organization concerned to reach the target or targets that will further define the creation of employee job performance. Improving the performance of the teacher can be done by increasing the motivation of teachers. Steers (1985) said the ability, temperament and interests work are the traits of individuals that determine the ability of workers to contribute to an organization as a counterweight to the motivation of workers is crucial the will of workers to contribute capabilities that can affect work performance in a variety of ways.

For a teacher job satisfaction is very important. The teacher will improve his performance if it has a high job satisfaction. Job satisfaction, the suitability of the desired expectations of teachers with existing policies in madrasah is the factor that supports low or absence of the teacher job satisfaction. The improvement of achievement teachers' work can be done by increasing job satisfaction of teachers.

Someone who has a high job satisfaction will have a positive attitude towards work. Conversely, a person will have a negative attitude if he felt dissatisfied with his work (Davis \& Newstrom, 1997). Based on the research results of Perrie and Baker (1997) showed support to the principal, student behavior, the condition of the school and teacher autonomy is closely related to teacher satisfaction.

This was reaffirmed by Hasibuan (2003) which states that the person employees tend to work vigorously when job satisfaction can be gained from work and job satisfaction is a key driver of morale, discipline, and performance in supporting the realization of the company's goals. Thus it can be seen job satisfaction is one of the main keys in the improvement of the quality of one's work, including teachers.

Increasing job satisfaction of teachers associated with the leadership of the headmaster; headmaster role in the management of resources contributes a large madrasah on achieving job satisfaction of teachers at the school. This was confirmed by Webb (2009) that principal as leader of the school greatly affects job satisfaction, comfort, and the level of achievement of a school. Job satisfaction indicator looks at the low absenteeism, turnover, and the level of complaints. Thus the teacher job satisfaction can be improved not only from teachers themselves but can through the active role of a headmaster. 
In addition, the increase in teachers' performance has a strong relationship with working environment. Teachers will feel comfortable in implementing the learning process at school when the madrasah has nice working atmosphere.

\section{Conclusion}

It can be concluded that there is a positive and significant relationship between job satisfaction and working conditions, teachers' motivation and job performance. The relationship between two variables is based on regression analysis and correlation. The results of this study indicate that when the teacher job satisfaction and work atmosphere has increased both, will positively affect teachers' motivation and job performance.

Improving performance of the teacher requires qualities of a headmaster, having high competence, professionalism and a strong dedication to improve the quality of education in madrasah.

The learning process requires teachers are creative and effective and have good qualities. The teacher has the motivation in teaching can deliver greater value in any ongoing learning process. An increase in the quality of the learning process is generated by teachers who have high motivation. Motivation becomes self-supporting and reinforcing in the face of any problems related to the learning process, though in a state of deficiency both in terms of facilities and funding infrastructures the teacher is able to maximize every learning process that takes place at the school.

In addition, job satisfaction held by teachers in madrasah will fulfill the wishes and expectations of teachers who have achieved even exceed the desires and expectations of teachers.

That is no less important in improving the performance of the teacher is a good working atmosphere, Working atmosphere at school is formed from the interaction between the components of the madrasah as headmaster, teachers, students and the environment. Teachers will feel calm, relaxed and comfortable when working atmosphere is good in madrasah. The learning process will not work without a good working atmosphere in madrasah, although madrasah have qualified teacher resources.

The existence of the meetings and the provision of high responsibility of the teachers in a variety of activities in madrasah can provide encouragement and motivation of teachers to work better. The existence of the responsibilities given to the headmaster of the teachers shows high trust and the quality of teachers, so that teachers feel valued and respected as part of the madrasah. Not only as a faculty alone but more than that is a driving force in improving the quality of education in madrasah. Formation of intense communication to others in madrasah is one way of maintaining a good working atmosphere. Communication between fellow provide a harmonious relationship, so that any problems can be seen in madrasah and resolved quickly so as not to damage the harmonious working atmosphere in the madrasah.

\section{References}

Adams, B. (2006). Memahami Segalanya tentang Kepemimpinan (Terjemahan oleh A. Sindoro). Batam: Penerbit Karisma Publishing Group.

Anoraga, P. (2006). Psikologi Kerja, Jakarta: Rhineka Cipta.

As'ad, M. (1995). Psikologi industri. Yogyakarta: Liberty.

Azeem, S. M. (2010). Job Satisfaction and Organizational Commitment among Employees in the Sultanate of Oman. Scientific Research, 1, 295-299. http://dx.doi.org/10.4236/psych.2010.14038

Azizy, A. Q. (2004). Melawan Globalisasi. Yogyakarta: Pustaka Pelajar.

Best, J. W. (1982). Metodologi Penelitian. Surabaya: Usaha Nasional.

Bishay, A. (1996). Teacher Motivation and Job Satisfaction: A Study Employing the Experience Sampling Meethod. Journal of Undergraduate Sciences, 3, 147-154.

Boles, J., Madupalli, R., Rutherford, B., \& Wood, J. A. (2007). The Relationship of Facets of Salesperson Job Satisfaction with Affective Organizational Commitment. Journal of Business \& Industrial Marketing, 22(5), 311-321. http://dx.doi.org/10.1108/08858620710773440

Davis, K. (2001). Perilaku Organisasi. Penerjemah Erly Suandy, Salemba Empat, Jakarta.

Davis, K. (2004). Fundamental Organization Behavior. Diterjemahkan Agus Dharma, Jakarta: Penerbit Erlangga.

Davis, K., \& Newstrom, J. W. (1997). Organizational behavior: Human behavior at work. New York: The Mcgraw-Hill Companies Inc. 
Donelly, J. H., Gibson, Jr. J. L., \& Ivancevich, J. M. (1984). Management. USA: Business Publication Inc.

Fink, D., \& Brayman, C. (2006). School leadership succession and the challenges of change. Educational Administration Quarterly, 42(1), 62-89. http://dx.doi.org/10.1177/0013161X05278186

Flippo, E. G. (1995). Personnel Management. New York: MacGrawHill.

Gagne, R. M., \& Briggs, L. J. (1979). Principles ot instructional Design (2nd ed.). New York: United States of America.

Gibson, Ivancevich, \& Donelly. (1997). Organization: Behavior structur process. USA: Richard D Irwin, A Times Mirror Higher Education Group.

Gomes, F.C. (2001). Manajemen Sumber Daya Manusia. Yogyakarta: Andi Offset.

Hasibuan, M. (1996). Organisasi dan Motivasi \& Dasar-Dasar Peningkatan Produktivitas. Jakarta: Bumi Aksara.

Hasibuan, M. (2003). Organisasi dan Motivasi: Dasar Peningkatan Produktivitas. Jakarta: Bumi Aksara.

Heidjrachman, R., \& Husnan, S. (1997). Manajemen Personalia. Yogyakarta: BPFE.

Hoy, W. K., \& Miskel, C. G. (1978). Educational Administration Theory Research and Practice. USA: Random House Inc.

Hughes, V. M. (2006). Teacher Evaluation Practices and Teacher Job Satisfaction. Makalah dipresentasikan untuk the Faculty of the GraduateSchool University of Missouri-Columbia.

Kerlinger, F. N. (1993). Foundation of Behavior Research. Ed. Ke-2 New York: Holt Saunder.

Kreitner, R., \& Kinicki, A. (2003). Perilaku Organisasi. Terjemahan: Erly Suandy, Edisi Pertama, Jakarta: Penerbit Salemba Empat.

Lo, M. C., \& Ramayah, T. (2011). Mentoring and job satisfaction in Malaysian SMEs. Journal of Management Development, 30(4), 427-440. http://dx.doi.org/10.1108/02621711111126891

Luthans, F. (2006). Perilaku Organisasi. Edisi Sepuluh, Yogyakarta: Penerbit Andi.

Mangkunegara, A. P. (2004). Manajemen Sumber Daya Manusia Perusahaan. Bandung: PT. Remaja Rosdakarya.

Manullang. M. (2008). Manajemen Personalia. Edisi Ke-4 Yogyakarta: Gadjah Mada University Press.

Mulyasa, E. (2007). Standar Kompetensi dan Sertifikasi Guru. Bandung: Remaja Rosdakarya.

Munandar, A. S. (2001). Psikologi Industri dan Organisasi. Jakarta: Universitas Indonesia.

Nasution, S. (2000). Didaktik Asas-asas Mengajar. Bandung: Remaja Rosdakarya, cet 2.

Nazir. (1988). Metode Penelitian, Jakarta: Ghalia Indonesia.

Perrie, M., \& Baker, D. P. (1997). Job Satisfaction among American Teacher Effict Workable Condition, Background Charakteritic and Teacher Compensation. New Jersey.

Poerwopoespito \& Utomo. (2000). Mengatasi Krisis Manusia di Perusahaan. Solusi melalui Pengembangan Sikap Mental. Jakarta: PT.Gramedia Widiasaran Indonesia.

Robbins, S. P. (2001). Perilaku Organisasi. Buku I, Edisi 9, Jakarta Gramedia.

Robbins, S. P. (2003). Perilaku Organisasi. Diterjemahkan oleh Tim Indeks. Jakarta: Penerbit Indeks Kelompok Gramedia,

Sanusi, A. (1992). Beberapa Dimensi Mutu Pendidikan. Bandung: FPS IKIP Bandung.

Sartika, I. D. (1999). Mutu Total STPDN: Kontribusi Budaya Organisasi yang Berorientasi Manajemen Mutu Total, Kepuasan Kerja dan Tahapan Mutu Terhadap Kinerja Pengelola Dosen Tetap STPDN. Disertai, FPS IKIP Bandumg, tidak iterbitkan.

Siagian, S. P. (1986). Filsafat Administrasi. Jakarta: CV. Haji Masagung.

Siagian, S. P. (2002). Kiat meningkatkan Produktivitas Kerja. Cetakan Pertama. Jakarta: Rineka Cipta.

Siagian, S. P. (2006). Manajemen Sumber Daya Manusia. Edisi Satu. Cetakan ketigabelas. Jakarta: Bumi Aksara. 
Sidi, I. D. (2000). Pendidikan dan Peran Guru Dalam Era Globalisasi. dalam majalah Komunika No. 25/tahun VIII.

Soeprihatno, J. (1996). Penilaian Kinerja dan Pengembangan Karyawan. Edisi Ke I, Cetakan Kedua, Yogyakarta: BPFE.

Sopiah. (2008). Perilaku Organisasional. Yogyakarta: Penerbit Andi.

Steers, M. R. (1985). Organization Effectiveness: A Behaviour View. Diterjemahkan: Madgalena Jamin, Efektivitas Organisasi: Kaidah Perilaku, Cetakan Kedua, Jakarta: Erlangga.

Supriadi, D. (1998). Mengangkat Citra dan Martabat Guru. Yogyakarta: Adicita Karya Nusa.

Suryabrata, S. (1992). Metodologi Penelitian. Jakarta: CV. Rajawali.

Sutrisno, E. (2009). Manajemen Sumber Daya Manusia. Edisi Pertama, Cetakan Pertama, Jakarta: Penerbit Kencana.

Suwar. (2008). Persepsi Guru Terhadap Kepemimpinan Kepala Sekolah dengan Motivasi Kerja dan Kepuasan Kerja.

Tempe, D. (1992). Kinerja. Jakarta: PT. Elex Media Komputerindo.

Uwes, S. (2004). Perencanaan Pendidikan. Bandung: Logos.

Webb, K. S. (2009). Creating satisfied employees in Christian higher education: Research on leadership competencies. Christian Higher Education, 8(1), 18-31. http://dx.doi.org/10.1080/15363750802171073

\section{Copyrights}

Copyright for this article is retained by the author(s), with first publication rights granted to the journal.

This is an open-access article distributed under the terms and conditions of the Creative Commons Attribution license (http://creativecommons.org/licenses/by/3.0/). 